\title{
PREDIKTOR PENGAMBILAN KEPUTUSAN UNTUK MENYUSUI EKSKLUSIF PADA IBU PASKA BEDAH SESAR
}

\author{
${\text { Isyti' } \operatorname{aroh}^{1,2^{*}} \text {,Setyowati }}^{3}$, Efy Afifah ${ }^{3}$ \\ 1. STIKES Muhammadiyah Pekalongan, Pekalongan 51172, Indonesia \\ 2. Program Studi Magister, Fakultas Ilmu Keperawatan, Universitas Indonesia, Depok 16424, Indonesia \\ 3. Fakultas Ilmu Keperawatan, Universitas Indonesia, Depok 16424, Indonesia \\ *E-mail: isytiaroh@yahoo.co.id
}

\begin{abstract}
Abstrak
Bayi 0-6 bulan memerlukan ASI eksklusif untuk pertumbuhan dan perkembangannya. Akan tetapi berbagai kendala dirasakan ibu untuk menyusui eksklusif terutama pada ibu paska bedah sesar. Penelitian ini bertujuan mengetahui prediktor pengambilan keputusan untuk menyusui eksklusif pada ibu paska bedah sesar. Desain yang digunakan adalah potong lintang, dengan 97 responden, dan analisis data dengan regresi logistik berganda. Hasil penelitian menunjukkan $53.6 \%$ responden memutuskan untuk menyusui eksklusif. Prediktor pengambilan keputusan untuk menyusui eksklusif adalah paparan informasi, pengetahuan, sikap tentang menyusui eksklusif, dukungan keluarga, dan dukungan petugas kesehatan, sedangkan yang tidak berhubungan adalah umur, pendidikan, paritas, dan nyeri. Prediktor paling dominan yang mempengaruhi pengambilan keputusan untuk menyusui eksklusif adalah sikap yang baik tentang menyusui eksklusif. Penelitian ini merekomendasikan agar mempertimbangkan sikap tentang menyusui eksklusif, pengetahuan tentang menyusui eksklusif, dukungan keluarga, dukungan petugas kesehatan dan penyebaran informasi tentang menyusui untuk mensukseskan program menyusui eksklusif.
\end{abstract}

Kata kunci: menyusui eksklusif, paska bedah sesar, pengambilan keputusan

\begin{abstract}
Predictors of Decision Making to Exclusive Breastfeeding of Post Cesarean Section Mother. The baby aged 0-6 month needs exclusive breastfeeding for growth and development. However, the constraints were found by the mother to exclusive breastfeeding, especially for mother after cesarean section. This study aimed to identify the predicting factors related to the exclusive breastfeeding decision-making of mothers post caesarean section. This study applied cross sectional design with 97 respondents. The data are analyzed using multiple logistic regressions. The result showed that $53.6 \%$ of respondents decided to provide exclusive breastfeeding. Factors related to exclusive breastfeeding decision-making were attitudes about exclusive breastfeeding, knowledge, family support, and health professionals' support, while unrelated factors were age, pain history, parity, and education. The most dominant factor associated with exclusive breastfeeding decision-making was attitude about exclusive breastfeeding. It is recommended to consider the attitudes, knowledge, family support, health professionals' support, and providing information about breastfeeding to succeess the exclusive breastfeeding programs.
\end{abstract}

Keywords: caesarean section, decision-making, exclusive breastfeeding

\section{Pendahuluan}

ASI eksklusif adalah makanan yang terbaik untuk bayi baru lahir usia 0-6 bulan (Perry, Hockenberry, Loedermilk, Wilson, \& Wong, 2010). ASI tidak hanya memberikan manfaat untuk bayi tetapi juga pada ibu. Sayangnya, cakupan ASI eksklusif di Indonesia masih rendah yaitu sebesar $45,4 \%$ pada bayi usia $0-1$ bulan, 38,3\% pada bayi usia $2-3$ bulan, dan $31,0 \%$ pada bayi usia $4-5$ bulan (Badan Penelitian dan Pengembangan Kesehatan Departemen Kesehatan Republik Indonesia, 2010).

Keputusan ibu untuk menyusui eksklusif merupakan hal yang sangat penting. Ada beberapa faktor yang mempengaruhi keputusan ibu untuk menyusui eksklusif yaitu faktor bayi, ibu dan 
faktor lainnya. Faktor bayi, menyangkut kondisi bayi yaitu Bayi Berat Lahir Rendah (BBLR) dan kelainan congenital Faktor ibu meliputi fisik yaitu penyakit kronis, komplikasi persalinan; dan psikologis seperti depresi, kecemasan, persepsi yang tidak tepat. Faktor keluarga yaitu dukungan suami, orang tua dan mertua. Faktor petugas kesehatan yaitu dukungan petugas kesehatan. Faktor sosial budaya yaitu nilai dan mitos di masyarakat tentang ASI dan faktor paparan informasi (pengetahuan yang diperoleh dari media televisi, koran atau radio) (Perry, et al., 2010; Riordan \& Wambach, 2010). Pada ibu dengan paska bedah sesar, faktor yang mempengaruhi lebih komplek dibandingkan dengan ibu bersalin normal (Riordan \& Wambach, 2010). Nyeri akibat luka insisi, kelelahan dan ketidaknyamanan menjadi faktor tambahan yang mempengaruhi ibu untuk menyusui segera setelah lahir.

Terkait dengan pengambilan keputusan, ada beberapa faktor yang dapat mempengaruhi ibu dalam pengambilan keputusan. Berdasarkan penelitian Setyowati (2003) tentang nutrisi, perempuan berada di urutan terbawah dalam pengambil keputusan keluarga. Pengambil keputusan utama adalah suami atau orangtua. Juliastuty, Setyowati, dan Afiyanti (2008) juga menemukan faktor internal dan eksternal yang mempengaruhi prempuan dalam pengambilan keputusan tentang kontrasepsi. Faktor internal meliputi pilihan personal, pengetahuan, pengalaman, keyakinan gender dan kesehatan diri. Faktor eksternal meliputi dukungan/hambatan sosial, pelayanan KB, KIE, dan bias gender. Kenyataan tersebut menjadikan otonomi perempuan lemah untuk memutuskan masalah yang terkait dengan kesehatan diri dan keluarganya, Pilihan menyusui eksklusif menjadi otonomi ibu, tetapi keputusan ibu juga bisa dipengaruhi oleh berbagai faktor.

Banyak penelitian tentang ASI eksklusif dan faktor yang mempengaruhinya tetapi penelitian tentang pengambilan keputusan untuk menyusui eksklusif pada ibu paska bedah sesar masih terbatas. Padahal mereka lebih banyak membutuhkan bantuan dan dukungan dibandingkan ibu bersalin normal dalam menyusui (Merten, Wyss, \& Ackermann-Liebrich, 2007). Tujuan penelitian adalah diketahuinya prediktor yang mempengaruhi pengambilan keputusan menyusui eksklusif pada ibu paska bedah sesar.

\section{Metode}

Prediktor dalam penelitian ini adalah karakteristik responden (umur, tingkat pendidikan, paritas); paparan informasi; tingkat pengetahuan; sikap; riwayat nyeri pasca persalinan seksio sesarea; dukungan keluarga; dan dukungan petugas kesehatan. Penelitian berlangsung sekitar lima bulan di Kabupaten Pekalongan, Jawa Tengah. Kriteria inklusi adalah Ibu paska bedah sesar yang bertempat tinggal di wilayah Kabupaten Pekalongan dengan usia bayi tiga hari sampai enam bulan, tidak mempunyai komplikasi atau penyakit lain yang menganggu kesehatan seperti perdarahan, infeksi atau sepsis paska bedah sesar, tidak mempunyai penyakit kronis yang menjadi hambatan menyusui eksklusif seperti kanker payudara dan bayi dilakukan rawat gabung.

Penelitian potong lintang ini melibatkan 97 responden yang diperoleh dengan teknik consecutive sampling. Instrumen penelitian adalah kuesioner tentang pengambilan keputusan, umur ibu, pendidikan, paritas, riwayat paparan informasi tentang menyusui eksklusif, pengetahuan tentang menyusui eksklusif, sikap terhadap menyusui eksklusif, riwayat nyeri, dukungan keluarga, dukungan petugas kesehatan dan lembar observasi tentang perilaku dalam menyusui eksklusif. Instrumen ini diuji validitas dan reliabilitasnya. Pengolahan data menggunakan regresi logistik berganda. Penelitian ini mendapatkan persetujuan dari komite etik Fakultas Ilmu Keperawatan UI dan menerapkan prinsip etik kepada subyek penelitian.

\section{Hasil}

Rerata umur responden adalah 28,85 tahun (tabel 1). Pendidikan dasar setingkat SD dan SMP merupakan tingkat pendidikan terbanyak $(43,3 \%)$. Paritas, responden terbanyak adalah 
multipara $(61,9 \%)$. Sebagian besar responden sudah terpapar informasi tentang ASI eksklusif $(63,9 \%)$, mayoritas responden berpengetahuan tinggi $(54,6 \%)$ dan paling banyak bersikap baik terhadap menyusui eksklusif $(53,6 \%)$. Pada variabel riwayat nyeri menunjukkan sebagian besar merasakan nyeri pasca bedah $(82,47 \%)$. Responden sebagian besar $(53,6 \%)$ mendapatkan dukungan keluarga dan dukungan petugas kesehatan $(54,6 \%)$ (lihat Tabel 2).
Prediktor pengambilan keputusan menyusui eksklusif pada ibu paska bedah sesar antara lain riwayat paparan informasi $(\mathrm{p}=0,015 ; 95 \%$ CI 1,217-6,766), tingkat pengetahuan $(\mathrm{p}=$ 0,007; 95\% CI 1,345-7,093), sikap ( $\mathrm{p}=0,000$; 95\% CI 5,492-39,35), dukungan keluarga ( $\mathrm{p}=$ 0,000; 95\% CI 3,641-23,08), dan dukungan petugas kesehatan ( $\mathrm{p}=0,000$; 95 CI 1,9010,52). Hasil uji selengkapnya disajikan pada Tabel 3.

Tabel 1. Distribusi Responden Menurut Umur

\begin{tabular}{ccccc}
\hline Variabel & Mean & Standar Deviasi & Minimal-Maksimal & 95\% CI \\
\hline Umur & 28,85 & 4,923 & $17-42$ & $27,85-29,84$ \\
\hline
\end{tabular}

Tabel 2. Proporsi Responden Menurut Tingkat Pendidikan, Paritas, Paparan Informasi, Tingkat Pengetahuan, Sikap, Riwayat Nyeri, Dukungan Keluarga, dan Dukungan Petugas Kesehatan

\begin{tabular}{|c|c|c|}
\hline Variabel & Jumlah $(n=97)$ & Persentase \\
\hline \multicolumn{3}{|l|}{ Tingkat Pendidikan } \\
\hline a. Dasar & 42 & 43,3 \\
\hline b. Menengah & 30 & 30,9 \\
\hline c. Tinggi & 25 & 25,8 \\
\hline \multicolumn{3}{|l|}{ Paritas } \\
\hline a. Primipara & 37 & 38,1 \\
\hline b. Multipara & 60 & 61,9 \\
\hline \multicolumn{3}{|l|}{ Paparan Informasi } \\
\hline a. Belum terpapar & 35 & 36,1 \\
\hline b. Sudah terpapar & 62 & 63,9 \\
\hline \multirow{2}{*}{$\begin{array}{l}\text { Tingkat Pengetahuan tentang ASI Eksklusif } \\
\text { a. Rendah }\end{array}$} & 44 & 45,4 \\
\hline & 53 & 54,6 \\
\hline \multicolumn{3}{|l|}{ b. Tinggi } \\
\hline Sikap & 45 & 46,4 \\
\hline a. Kurang baik & 52 & 53,6 \\
\hline b. Baik & & \\
\hline Riwayat Nyeri & 80 & 82,47 \\
\hline a. Merasakan nyeri & 17 & 17,53 \\
\hline \multicolumn{3}{|l|}{ b. Tidak merasakan nyeri } \\
\hline Dukungan Keluarga & 45 & 46,4 \\
\hline a. Tidak mendukung & 52 & 53,6 \\
\hline b. Mendukung & & \\
\hline Dukungan Petugas Kesehatan & 44 & 45,4 \\
\hline a. Tidak mendukung & 53 & 54,6 \\
\hline b. Mendukung & & \\
\hline
\end{tabular}


Tabel 3. Karakteristik Responden dengan Pengambilan Keputusan Menyusui Eksklusif

\begin{tabular}{|c|c|c|c|c|c|c|c|c|}
\hline \multirow{3}{*}{ Variabel } & \multicolumn{4}{|c|}{ Keputusan Pemberian ASI Eksklusif } & \multicolumn{2}{|c|}{ Total } & \multirow{3}{*}{ 95\% CI } & \multirow{3}{*}{$p$} \\
\hline & \multicolumn{2}{|c|}{ Ya } & \multicolumn{2}{|c|}{ Tidak } & \multirow{2}{*}{$\mathbf{N}(\mathbf{9 7})$} & \multirow{2}{*}{$\%$} & & \\
\hline & $\mathbf{n}$ & $\%$ & $\mathbf{n}$ & $\%$ & & & & \\
\hline \multicolumn{9}{|l|}{ Paparan Informasi } \\
\hline a. Belum terpapar & 13 & 37,14 & 22 & 62,86 & 35 & 100 & $1,217-6,766$ & $0,015^{*}$ \\
\hline b. Sudah terpapar & 39 & 62,90 & 23 & 37,10 & 62 & 100 & & \\
\hline \multicolumn{9}{|l|}{ Tingkat Pengetahuan } \\
\hline a. Rendah & 17 & 38,64 & 27 & 61,36 & 44 & 100 & $1,345-7,093$ & $0,007 *$ \\
\hline b. Tinggi & 35 & 66,04 & 18 & 33,96 & 53 & 100 & & \\
\hline \multicolumn{9}{|l|}{ Sikap } \\
\hline a. Kurang baik & 10 & 22,22 & 35 & 77,78 & 45 & 100 & $5,492-39,35$ & $0,000^{*}$ \\
\hline b. Baik & 42 & 80,77 & 10 & 19,23 & 52 & 100 & & \\
\hline \multicolumn{9}{|l|}{ Dukungan keluarga } \\
\hline a. Tidak Mendukung & 12 & 26,67 & 33 & 73,33 & 45 & 100 & $3,641-23,08$ & $0,000^{*}$ \\
\hline b. Mendukung & 40 & 76,92 & 12 & 23,07 & 52 & 100 & & \\
\hline \multicolumn{9}{|c|}{ Dukungan Petugas Kesehatan } \\
\hline a. Tidak Mendukung & 15 & 34,09 & 29 & 65,91 & 44 & 100 & $1,90-10,522$ & $0,000 *$ \\
\hline b. Mendukung & 37 & 69,81 & 16 & 30,19 & 53 & 100 & & \\
\hline
\end{tabular}

*Bermakna pada $\alpha<0,05$

Tabel 4. Prediktor paling Berhubungan dengan Pengambilan Keputusan Menyusui Eksklusif pada Ibu Paska Bedah Sesar

\begin{tabular}{lcccc}
\hline Variabel & B & $\boldsymbol{p}$ Wald & Odds Ratio & 95\% CI \\
\hline Sikap & 2,56 & 15,15 & 12,92 & $3,56-46,87$ \\
Konstanta & $-14,96$ & 22,33 & & \\
\hline
\end{tabular}

Prediktor Paling Dominan Berhubungan dengan Pengambilan Keputusan Menyusui Eksklusif pada Ibu Paska Bedah Sesar. Hasil uji statistik untuk menentukan prediktor paling dominan berhubungan dengan pengambilan keputusan menyusui eksklusif pada ibu paska bedah sesar dapat dilihat pada Tabel 4.

Hasil uji regresi logistik diketahui prediktor paling dominan berhubungan dengan pengambilan keputusan adalah sikap tentang menyusui eksklusif dengan $p$ Wald 15,149 (OR=12,921; 95\% CI 3,562-46,874). Responden yang bersikap baik terhadap pemberian ASI eksklusif juga berpeluang untuk memutuskan menyusui eksklusif 13 kali lebih besar dibandingkan dengan responden yang bersikap kurang baik terhadap menyusui eksklusif.

\section{Pembahasan}

Hasil penelitian membuktikan prediktor yang berhubungan dengan pengambilan keputusan menyusui eksklusif pada ibu paska bedah sesar adalah paparan informasi, sikap terhadap menyusui eksklusif, pengetahuan tentang menyusui eksklusif, dukungan keluarga dan dukungan petugas kesehatan. Prediktor paling berhubungan 
adalah sikap terhadap menyusui eksklusif artinya adalah ibu paska bedah sesar yang bersikap baik terhadap menyusui eksklusif mempunyai peluang paling besar memutuskan menyusui eksklusif. Sikap yang baik terhadap menyusui eksklusif tercermin dari perilaku ibu untuk tetap menyusui eksklusif pada bayinya.

Hasil ini didukung oleh penelitian sebelumnya dari Zhou, Younger, dan Kearney (2010) yang menyatakan bahwa sikap tidak suka menyusui merupakan faktor paling dominan yang mempengaruhi perilaku tidak menyusui. Demikian pula dengan penelitian Wambach dan Cole (2000) juga membuktikan bahwa sikap berhubungan dengan pengambilan keputusan ibu untuk menyusui bayinya. Penelitian Bai, Middlestadt, Peng, dan Fly (2009) tentang faktor yang mempengaruhi keputusan meneruskan pemberian ASI sampai usia 6 bulan, menunjukkan bahwa sikap merupakan faktor yang paling mempengaruhi keputusan tersebut.

Kenyataan tersebut sesuai dengan teori reasoned action and planned behavior yang dikemukakan oleh Ajzen dan Fishbein (1975, dalam Peterson \& Bredow 2004) bahwa sikap adalah salah satu faktor yang mempengaruhi niat untuk melakukan sesuatu di samping faktor norma subyektif dan persepsi terhadap suatu perilaku. Faktor sikap lebih mempengaruhi niat seseorang untuk melakukan suatu perilaku. Hal ini disebabkan karena beberapa alasan yaitu sikap merupakan kecenderungan berfikir, berpersepsi dan bertindak; sikap mempunyai daya pendorong; sikap relatif lebih menetap dibanding emosi dan pikiran; dan sikap mengandung aspek penilaian atau evaluasi terhadap obyek (Peterson \& Bredow, 2004; Notoatmodjo, 2010).

Penelitian Peters, Wehkamp, Felberbaum, Krüger, dan Linder (2005) tentang faktor yang mempengaruhi keputusan lama menyusui menunjukkan hasil sebaliknya. Faktor pengetahuan adalah faktor paling dominan yang mempengaruhi keputusan tentang lama menyusui. Faktor pengetahuan merupakan faktor paling dominan karena pengetahuan mendasari seseorang untuk bersikap. Pengetahuan yang baik menjadikan seseorang cenderung bersikap baik pula.

Faktor lain yang berhubungan dengan pengambilan keputusan untuk menyusui eksklusif pada ibu paska bedah sesar adalah tingkat pengetahuan. Hasil penelitian ini diperkuat dengan penelitian Tamiru, Belachew, Loha, dan Mohammed (2012) pada ibu yang tidak memberikan ASI segera pada satu jam pertama kehidupan. Kurangnya pengetahuan berhubungan dengan kurang optimalnya pemberian ASI pada satu jam pertama kehidupan. Ibu yang kurang pengetahuan tentang keistimewaan ASI dibandingkan susu formula cenderung berpersepsi bahwa ASI dan susu formula sama saja kualitasnya. Apalagi gencarnya promosi susu formula, dapat merubah persepsi masyarakat tentang keunggulan ASI dibandingkan susu formula.

Dukungan keluarga juga berhubungan dengan pengambilan keputusan untuk menyusui eksklusif pada ibu paska bedah sesar. Ibu yang mendapatkan dukungan keluarga lebih banyak yang menyusui eksklusif dibandingkan dengan ibu yang tidak mendapatkan dukungan keluarga. Dukungan keluarga yang dimaksudkan dalam penelitian ini adalah dukungan berupa barang, jasa, informasi dan emosional. Penelitian tersebut sesuai dengan penelitian Kong dan Lee (2004) bahwa dukungan suami berpengaruh terhadap keputusan menyusui eksklusif. Penelitian Februhartanty (2008) juga membuktikan sikap suami yang baik berhubungan dengan keputusan ibu untuk menyusui.

Faktor petugas kesehatan juga menunjukkan hasil yang sama. Petugas kesehatan adalah orang yang dianggap memahami permasalahan kesehatan dan dukungannya diperlukan untuk memberi pemahaman tentang pentingnya menyusui eksklusif, cara sukses memberikan ASI eksklusif dan mengatasi hambatan atau kesulitan dalam menyusui. Penelitian tentang pentingnya dukungan petugas kesehatan terhadap keberhasilan menyusui eksklusif telah dilakukan oleh beberapa peneliti. Penelitian Britton, McCormick, Renfrew, Wade, dan King (2007) 
menyebutkan bahwa ibu yang mendapat dukungan dari tenaga professional dalam menyusui secara signifikan berhubungan dengan lama menyusui eksklusif. Petugas kesehatan yang menunjukkan sikap siap membantu kesulitan ibu, dapat meningkatkan kepercayaan diri ibu untuk menyusui bayinya. Martis (2007) mengemukakan hasil berbeda dari penelitian ini. Kelompok perlakuan diberi dukungan ekstra oleh petugas kesehatan dan kelompok kontrol diberikan dukungan oleh kesehatan seperti biasa. Hasil penelitian tersebut menunjukkan bahwa ekstra dukungan oleh petugas kesehatan tidak berhubungan signifikan dengan lama menyusui termasuk menyusui eksklusif.

Hubungan antara riwayat paparan informasi dengan pengambilan keputusan untuk menyusui eksklusif menunjukkan ada hubungan yang signifikan. Informasi dan edukasi sangat penting untuk meningkatkan pengetahuan tentang menyusui eksklusif. Menurut teori cognitive learning perspective manusia mengalami proses pembelajaran ketika ada transformasi informasi dari lingkungan. Informasi tersebut membentuk pengetahuan yang disimpan dalam memorinya. Belajar terjadi ketika pengetahuan baru didapat atau pengetahuan lama dimodifikasi berdasarkan pengalaman (Schunk, 2008). Proses belajar tersebut akan membentuk kesadaran seseorang, selanjutnya kesadaran akan membentuk perilaku. Perilaku yang didasari oleh proses belajar relatif lebih lama menetap dibandingkan dengan perilaku yang tidak berdasarkan proses belajar.

Hasil penelitian tersebut sesuai dengan penelitian Pobocik, Benavente, Allison, Schwab, dan Boudreau (2000) dengan metoda Early Experiences and Counseling for Effective Lactation (EXCEL) yaitu pendampingan dan pemberian informasi serta konseling laktasi. Hasil penelitian membuktikan pendampingan dan pemberian informasi serta konseling laktasi dapat meningkatkan dilakukannya inisiasi menyusu dini dan meningkatkan lama pemberian ASI eksklusif. Demikian pula dengan Arora, McJunkin, Wehrer, dan Kuhn (2000) bahwa informasi yang diperoleh dari kelas prenatal, majalah, buku, dan TV mempengaruhi ibu untuk memilih menyusui bayinya dibandingkan dengan memberikan botol. Pemberian informasi dari berbagai sumber dapat meningkatkan pengetahuan tentang pentingnya ASI eksklusif.

Penelitian Abdillah, Hastuti, dan Sumarwan (2004) justru menghasilkan perbandingan terbalik antara kemudahan akses informasi ibu dengan perilaku ibu dalam memberikan ASI eksklusif. Pada ibu yang memiliki akses informasi lebih baik mempunyai peluang 0,7 kali lebih besar untuk tidak menyusui eksklusif dibandingkan dengan ibu yang mempunyai akses informasi kurang baik. Hal ini disebabkan informasi tentang susu formula lebih banyak dibandingkan dengan informasi tentang ASI, sehingga dapat mengubah pandangan masyarakat tentang ASI.

Perawat sebagai petugas kesehatan harus memfokuskan pada sikap ibu berkaitan dengan ASI eksklusif. Asuhan keperawatan yang memperhatikan sikap sebagai domain yang membentuk perilaku didahului dengan pengkajian komprehensif yang dapat menilai sikap seseorang. Tujuan dari asuhan keperawatan tersebut adalah memfasilitasi perubahan sikap terhadap ASI eksklusif ke arah yang positif. Selanjutnya sikap tersebut menjadi acuan perawat dalam memilih intervensi yang tidak menimbulkan resistensi.

\section{Kesimpulan}

Prediktor pengambilan keputusan untuk menyusui eksklusif pada ibu paska bedah sesar adalah tingkat pengetahuan yang tinggi tentang ASI eksklusif, sikap yang baik terhadap menyusui eksklusif, ibu mendapatkan dukungan keluarga, ibu mendapatkan dukungan petugas kesehatan dan riwayat paparan informasi sebelumnya. Faktor paling dominan adalah sikap. Hasil ini tidak berbeda dengan faktor yang mempengaruhi ibu yang bukan paska bedah sesar untuk menyusui eksklusif. Perawat dapat menyusun intervensi keperawatan yang dapat mempengaruhi ibu paska bedah sesar untuk menyusui eksklusif (AT, YA, INR). 


\section{Referensi}

Abdillah, S., Hastuti, D., dan Sumarwan, U. (2004). Pengambilan keputusan pemberian ASI eksklusif kepada bayi di Bogor. The Indonesian Journal of Community Nutrition \& Family Studies, 28(1), 70-77.

Arora, S., McJunkin, C., Wehrer, J., \& Kuhn, P. (2000). Major factors influencing breastfeeding rates: Mother's perception of father's attitude and milk supply. Pediatrics, 106(5), E67-73.

Badan Penelitian Pengembangan Kesehatan Departemen Kesehatan RI. (2010). Laporan nasional riset kesehatan dasar 2010. Jakarta: Kementrian Kesehatan Republik Indonesia.

Bai, Y., Middlestadt, S.E., Peng, C.Y., \& Fly, A.D. (2009). Predictors of continuation of exclusive breastfeeding for the first six months of life. $J$ of human lactation, 26(1), 26-34.

Britton, C., McCormick, F.M., Renfrew, M.J., Wade, A., \& King, S.E. (2007). Support for breastfeeding mothers. Cochrane Database System: Review, 4(1), CD 001141. Diperoleh dari: http://www. ncbi.nlm.nih.gov/.

Februhartanty, J. (2008). Strategic roles of fathers in optimizing breastfeeding prac- tices: A study in an urban setting of Jakarta. Diperoleh dari: http://gizi.depkes. go.id/.

Juliastuty, D., Setyowati, \& Afianti,Y., (2008). Pengambilan keputusan pemakaian kontrasepsi pada ibu grande multipara di Kabupaten Tangerang: Studi grounded theory. Jurnal Keperawatan Indonesia, 12(1), 100-107.

Kong, S.K., \& Lee, D.T. (2004). Factors influencing decision to breastfeed. JAN, 46(4), 369-379.

Martis, R. (2007). Support for breastfeeding mothers. The WHO Reproductive Health Library. Geneva: World Health Organization. Diperoleh dari: http://apps.who.int/ rhl/pregnancy_childbirth/.
Merten, S., Wyss, C., \& Ackermann-Liebrich, U. (2007). Caesarean sections and breastfeeding initiation among migrants in Switzerland. Int J of Public Health, 52(4), 210-222.

Notoatmodjo, S. (2010). Ilmu perilaku manusia. Jakarta: Rineka Cipta.

Perry, S.E., Hockenberry, M.J., Loedermilk, D.L., Wilson, D., \& Wong, D.L. (2010). Maternal child nursing care. St Louis: Mosby Elsevier.

Peters, E., Wehkamp, K.H, Felberbaum, R.E., Krüger, D., \& Linder, R. (2005). Breastfeeding duration is determined by only a few factors. Eu J of Public Health, 16(2), 162167.

Peterson, S.J., \& Bredow, T.S. (2004). Middle range theories: Application to nursing research. Philadelphia: Lippincott Wil- liams $\&$ Wilkins.

Pobocik, R.S., Benavente, J.C., Allison, Schwab, C., \& Boudreau, N. (2000). Effect of a breastfeeding education and support program on breastfeeding initiation and duration in a culturally diverse group of adolescents. $J$ of Nutrition Education \& Behavior, 32(3), 139145.

Riordan, J., \& Wambach, K. (2010). Breastfeeding and human lactation. $4^{\text {th }} e d$. Sudbury: Jones $\&$ Bartlett Publishers.

Schunk, D.H. (2008). Learning theories: An educational perspective. London: Upper Saddle River N.J.

Setyowati. (2003). The impact of village midwives and candies in improving nutritional of pregnant women in selected rural villages in two districts Banten province Indonesia 2003: A longitudinal study. Makara Kesehatan, 14(1), 5-10.

Tamiru, D., Belachew, T., Loha, E., \& Mohammed, S. (2012). Sub-optimal breastfeeding of infants during the first six months and associated factors in rural communities of Jimma Arjo Woreda, Southwest Ethiopia. 
BMC Public Health, 12(1), 363. doi: 10.1186/1471-2458-12-363

Wambach, K.A., \& Cole, C. (2000). Breastfeeding and adolescents. JOGNN, 29(3), 282-294.
Zhou, Q., Younger, K.M., \& Kearney, J.M. (2010). An exploration of the knowledge and attitudes towards breastfeeding among a sample of Chinese mothers in Ireland. $B M C$ Public Health, 10(722), 1-11. 